\title{
The Impact of Technological and Structural Changes in the National Economy on the Labour-Capital Relations
}

\author{
Małgorzata Gawrycka, Aneta Sobiechowska-Ziegert ${ }^{1}$, Anna Szymczak ${ }^{2}$
}

\begin{abstract}
The aim of the research presented in this paper is to show the relations between labour and capital in the national economy, resulting from technological and structural changes taking place in the years 1991 to 2008 and to indicate of their importance for economic growth.

The paper presents the functional determinants for the Polish economy in 1991-2008 affecting the phenomenon subject to study as well as the preliminary analysis of relations between capital and labour and their impact on the GDP. In the research the econometric methods of description and inference based on the concept of macroeconomic Cobb-Douglas production function in both static and dynamic approach were used. The study shows that increase in production in the national economy was largely the result of capital growth during the analysed period. The main factor of economic growth however in the years 1998 to 2008 was the technological progress. The results may be the implication for economic policy in terms of investment and employment.
\end{abstract}

KEY WORDS: $\quad$ transformation, structural changes, employment, capital, national economy, macroeconomic production function

JEL Classification:

D40, 040

${ }^{1}$ Gdańsk University of Technology, POLAND

${ }^{2}$ Sopot College, POLAND

\section{Introduction}

The transformation of the Polish economy has contributed to the elimination of a number of distortions functioning on the labour market. Dynamic structural changes forming the basis for a new economic system - privatization and restructuring of enterprises in the initial transition period - led to both negative and positive changes on this market. From the standpoint of the labour market, the negative effects of impact of the implemented reforms include, inter alia, the loss of jobs and rising unemployment as well as decreased

Corespondence concerning to this article should be addressed to: mgaw@zie.pg.gda.pl professional activity of the population. The positive effect of the changes include the process of rationalisation of the labour resources consisting in the adaptation of the structure of involved resources and methods of their use to the existing economic conditions. Companies began to pay increasing attention to labour productivity. Available technical devices generated by the involved capital required adapting the labour resources to a level resulting from the economic calculation. The labour rationalization process is continuous and characteristic of any market economy. Only its causes change. One of them is striving to achieve a competitive advantage of companies and their further development. It should be emphasized that the increasing international mobility of production factors 

increased demand for labour. Whereas, capital-based technological progress reduces it. Thanks to the process of reallocation of labour resources across sectors of the national economy, technological progress does not necessarily have to lead to changes in the employment level in the long run (Bukowski \& Dyrda, 2009).

The aim of the research presented in this paper is to present the relationship between labour and capital in the national economy resulting from technological as well as structural changes taking place in the years from 1991 to 2008 and indication of their importance for economic growth.

Technological changes taking place in the economy depend on the achieved economic growth and the level of ongoing investment. Both processes are determined by changes in the external environment and institutional reforms on the labour market. The effects of structural reforms for the labour market with emphasis on technological changes are presented on the figure 1 . The number of jobs offered in the economy is influenced by labour demand and labour supply, together with its specific features. The demand for labour depends on the activity of the economy (economic growth) and technological changes that determine the intensity of the use of work and qualification requirements. Labour supply is determined primarily by two factors: the number of working-age population and the degree of the population's professional activity. The first of those factors is exogenous, because changes in the number of working-age population are largely determined by the birth rate from before at least 18 years. In the case of the second factor, the most significant seem to be the wages and the unemployment benefits, as well as legislation influencing the labour market.

Tangible investments are the main determinant of technological changes implemented in an enterprise. By increasing the amount of capital they contribute to the increase in the production capacity of the enterprise in the future. We must remember that a manufacturing process consumes physical capital. In order to maintain the existing capital stock it is necessary to reconstruct it. In the available sources the measure of capital accounting for both investment processes, as well as the amortisation of assets (depreciation) is the net value of fixed assets.

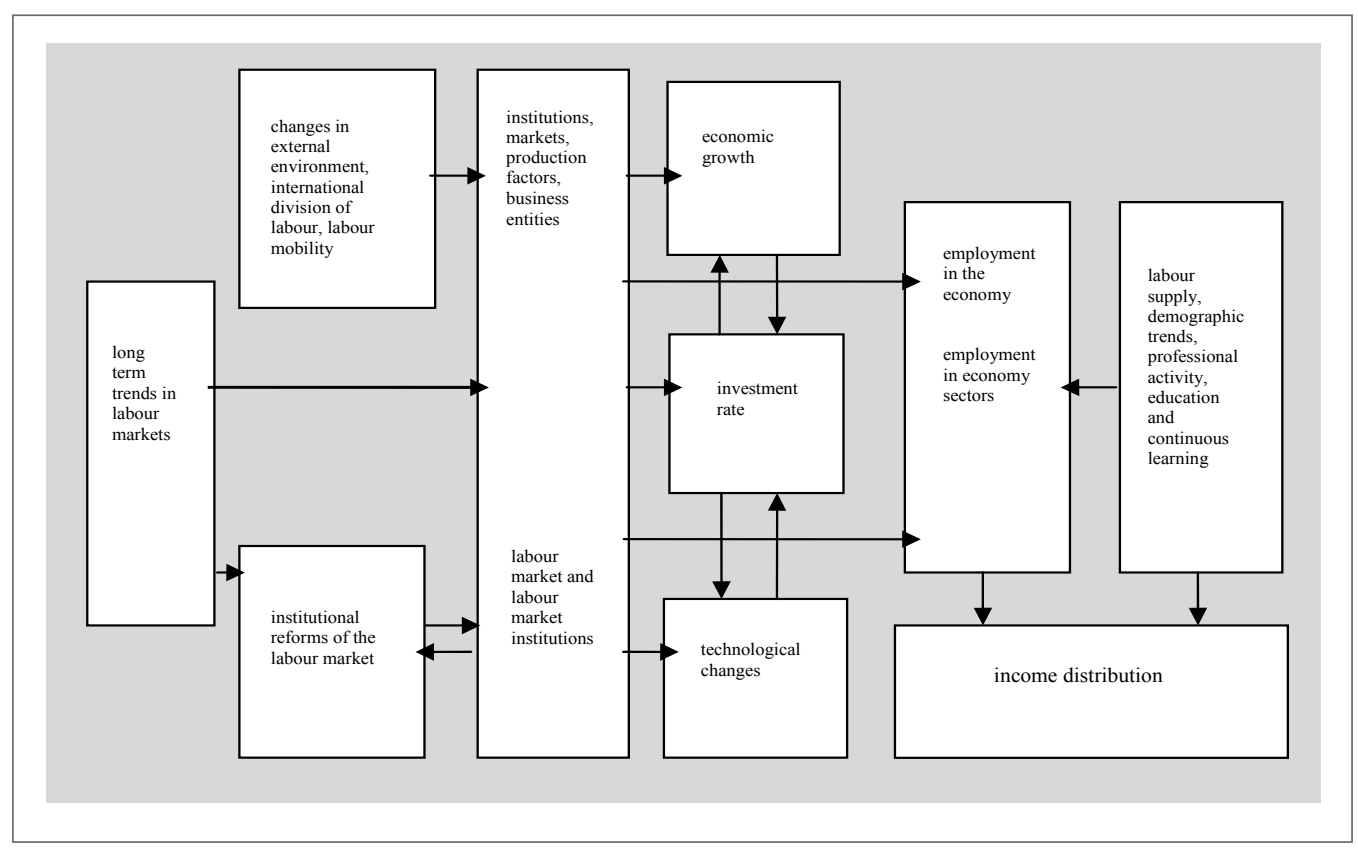

Figure 1. Impact of structural and technological changes on employment in national economy Note. Adapted from Weller, J. (2001). Economic reforms, growth and employment: Labor markets in Latin America and Caribbean. Chile: ECLAC. 

production against the scale of outlays. This elasticity is equal to the degree of homogeneity of function ${ }^{1}$ :

$$
E_{y / \lambda}=\frac{d \lambda y}{d \lambda} \times \frac{\lambda}{\lambda y}=\alpha_{1}+\alpha_{2}
$$

Thus, if all production factors simultaneously increase by $1 \%$, the production volume will increase by $\left(\alpha_{1}+\alpha_{2}\right) \%$

In order to measure the impact of technological change on the production value, it is necessary to choose the form of aggregate production function, which is associated with the adoption of certain assumptions on the structure of relations between the production factors and the impact of technological progress on them. For statistical data presented in the form of time series a dynamic Cobb-Douglas is often used which takes the following form:

$Y_{t}=e^{\alpha_{0}} \cdot C^{\alpha_{1}} \cdot L^{\alpha_{2}} \cdot e^{\alpha_{3} t} \cdot e^{\varepsilon_{t}}$

The time variable $t$ represents the so-called technical progress factor which means that the same level of labour and capital outlays leads to an increase in production. Therefore, we can say that in every period the value of production increases $e^{\alpha 3}$ times, i.e. the relative increase in the production value is $e^{\alpha 3}-1$.

The initial task in the construction of an econometric model is to define the independent variables. The selection criterion should be the substantive knowledge of the studied phenomenon. One should choose such factors (independent variables) that have a significant influence on the phenomenon studied (dependent variable). In this article, the production measure $\mathrm{Y}$ is the GDP at current prices, the value of labour $\mathrm{L}$ is the average employment in national economy and the capital $\mathrm{C}$ is the value of net assets.

Adopting the net value of fixed assets as a measure of capital can be debatable. The authors realise that the depreciated fixed assets may still be used in production processes and thus increase the GDP. In the CobbDouglas model, the capital may be the gross value of fixed assets (Tokarski, 2010). However, it appears that the measure of capital proposed in this paper - the net value of fixed assets - is consistent with the economic theory. The future capital resources may vary from the accumulated capital resources $\mathrm{C}_{1}$ in two ways. First, new capital can be invested (I). Secondly, amortisation may partially reduce the value of the capital resources. The new capital value will then amount to $C_{2}=C_{1}+I-$ $\delta C_{1}$. Where: $C_{2}$ is the new capital resources, $C_{1}$ - former capital, $I$ - gross investments, $\delta C_{1}$ - amortisation. $C_{2}$ corresponds to the net value of fixed assets. In order for the capital resources $\left(C_{2}\right)$ to grow, new investments must exceed amortisation (Burda \& Wyplosz, 2000). That measure of capital also provides greater diagnostic capabilities. By indicating the extent to which gross GDP depends on the value of this indicator, it draws the attention to the reconstruction and modernization processes increasing the efficiency of capital.

\section{Research results}

In the first years of transformation of Polish economy (1990-1994) a decline in production, measured in constant prices, could be observed. In the subject literature Lipowski and Winiecki point that the cause of this phenomenon was the structural deformation of the economy of real socialism, which was characterized by waste of resources, by both the consumer and producer (as cited in Bałtowski \& Miszewski, 2007, p. 200). The "market-redundant" industrial production representing an immanent feature of the centrally planned economy included, according to the classification of Lipowski (as cited in Bałtowski \& Miszewski, 2007, p. 200), three separate groups of production: unwanted production, irrational production and political production. An example of unwanted production may be excess storage of stocks accumulated by firms and households during the economy of shortages. The second group is the production of end-user goods at low prices (with high subsidies) used for consumption or further processing, frequently wasted. Political production means manufacturing of intermediate goods used for the realisation of investments provided for in the central plan undertaken without carrying out the investment efficiency calculation and military production produced in excess and at inflated costs.

Economic system reform began in 1989, amending the existing economic order, eliminated the features of the previous system, while contributing to a decline in

${ }^{1}$ The function is homogenous at the degree $\theta>0$ if $\forall \lambda>0 f(\lambda x)=f\left(\lambda x_{2}, \ldots, \lambda x_{k}\right)=\lambda^{\theta} f(x)$ 
production. A substantial part of economic potential of state-owned enterprises was destroyed and many areas of domestic production collapsed due to the lack of demand and the opening of the economy. According to a study by Lipowski, Glikman and Winiecki, the fall in production in the first years of transition was for the most part nothing more than getting rid of the structural deformation and the wastage of resources during the time of real socialism (as cited in Bałtowski \& Miszewski, 2007, p.206).

In the centrally planned economy, the labour market also functioned improperly. Guaranteed employment characteristic of the past regime (the so-called full employment) led to huge excess of employment, which is unemployment in the workplace. Recession and new rules of economic behaviour, as a result of the stabilization program, revealed unemployment. It must be emphasized that transformation changes in Poland coincided with the global industrial and information revolution by which the labour-consuming technologies were (and still are) replaced with laboursaving ones, which in turn contributed even more to the reduction of employment.

In subsequent years, i.e. after 1994, restructuring processes resulting from changes in the economic system were still under way. Therefore, when conducting the research there occurred a problem with the adoption of a relevant research period, so the phenomena described in the theoretical econometric models were carried out under comparable conditions of economic decision-making by business entities, i.e. in a situation when the distortions resulting from a centrally planned economy ceased to be relevant for the course of economic processes at the level of aggregated values. In addition, it was necessary to draw attention to the specificities of the economy, under which these models were created. They are frequently based on statistical data from countries with a far different level of economic development than the country the model is to refer to (Zienkowski, 2002).

The European Commission's Report of October 1999 showed that Poland (Ćwikliński, 2000) was evaluated as a positively developing market economy, which was confirmed by the observed changes in ownership structure, legal and institutional changes corresponding to the rules of market economy. The European Commission experts confirmed that the Polish economy is able to compete with other countries characterized by higher levels of development.

Accordingly, the authors decided to adopt the years 1998-2008 as the study period, assuming that in 1998 the next phase of construction of a market economy was completed.

The starting point for research is the preliminary analysis of changes in the GDP, the net values of fixed assets and employment in the Polish economy (presented on the figure 2).

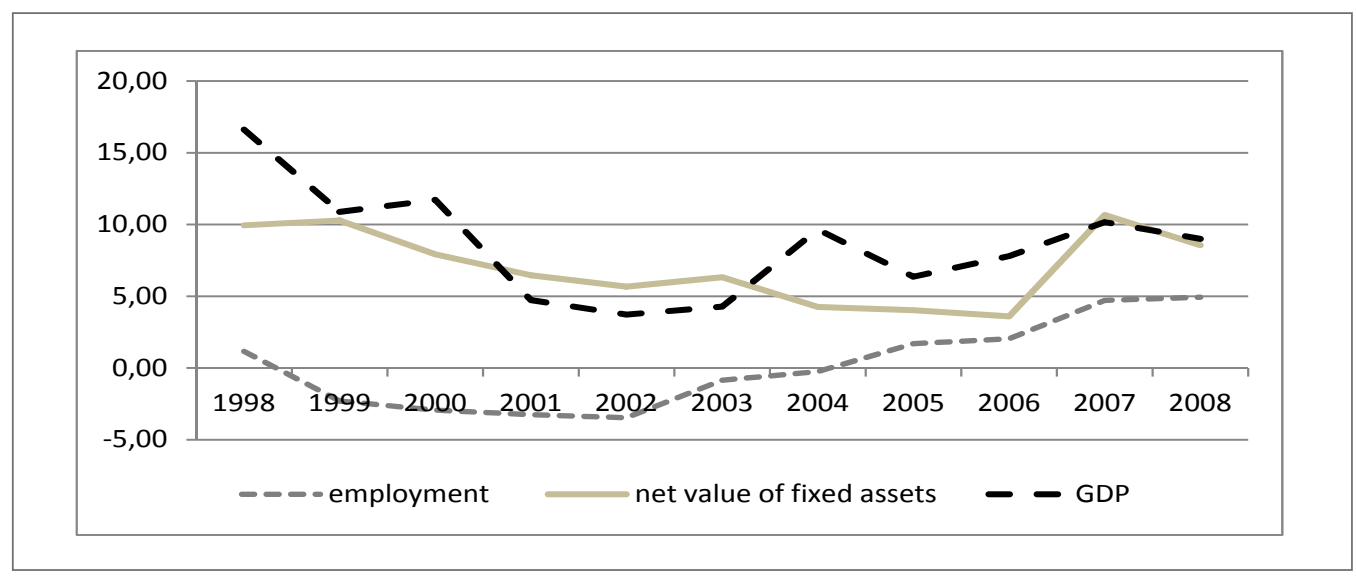

Figure 2. The rate of change of GDP, the net values of fixed assets and employment in 1998-2008 (compared to the previous period in \%, current prices)

Note. Based on data file available from http:// www.stat.gov.pl, access on 08.12.2010 
In the years 1998-2008, the average employment rate in the national economy showed some fluctuations. Until 2005, the average number of employees had been systematically declining. In subsequent years a systematic growth could be observed. In 2008, the average level of employment in the national economy was similar to that of 1998 adopted in this study as the base year and amounted to nearly 9,900 thousand people.

In 1999-2004, both GDP growth and the net value of fixed assets were characterized by a significant increase. By contrast, employment fell systematically. One can venture to say that in the years covered by the study, the GDP growth was largely affected by the increased investment in physical capital, which probably contributed to the further restructuring of employment.

In 1999, the pace of GDP growth and the net values of fixed assets were approximate and both reached over $10 \%$. Whereas, the average level of employment decreased by $2.3 \%$. It is worth noting year 2002 , when the pace of economic growth was $3.7 \%$ and was lower by nearly 2 p.p. than the net value of fixed assets amounting to $5.6 \%$. The average level of employment in the year under study decreased by more than $3 \%$. It must be noted that expenditures in fixed assets bring effect only in a later period, which may translate into an adjustment in the GDP growth in the future.

In 2005-2006, the pace of GDP growth was higher than the pace of growth of the net value of fixed assets and the average employment level. In 2007-2008, both the pace of GDP growth and the net values of fixed assets were similar and, for example in 2007, they reached over $10 \%$. On the other hand, in 2008 a similar pace of GDP and net assets value growth were observed, but they were lower than in the previous year - it amounted to more than $8 \%$ - while the average employment rate increased to $5 \%$.

Before estimating the parameters of the CobbDouglas function the correlation coefficients were calculated showing the strength of relations between the independent and the dependent variables. The analysis of correlation coefficients suggests that in 1991-2008, there was a negative average correlation between GDP and labour and a strong and positive correlation between GDP and capital. A detailed listing of correlation coefficients is given in the table 1 .

The negative relationship between the GDP and employment confirms the presence of strong structural changes in the Polish economy arising not only from the technological and structural changes consistent with the theory of Clark (1940); Fourastie (1954) and Fisher (1939), but also of structural changes arising from economic transition. In order to eliminate the influence of the last of the factors on the course of economic processes the period of research was limited to the years 1998-2008.

In order to determine the flexibility of production against labour and capital in the period under study, both the static function, given in formula (1) as well as dynamic, presented by equation (4) were estimated. Table 2 presents the results of the estimations of the static Cobb-Douglas function for Poland in the period 1998-2008. Analyzing the data in table 2, we can consider all the parameters as statistically significant at the significance level of 0.10 . The high value of the determination coefficient indicates that over $99 \%$ of the total variability in production was explained by the proposed model, and Godfrey statistic allows inferences about the absence of significant autocorrelation of the random component.

Therefore, we say that $1 \%$ increase in capital resulted during the analysed period in the increase of production of $1.18 \%$, provided the employment level was maintained. While $1 \%$ increase in employment contributed to the increase of production by $0.29 \%$, provided the capital level was stable. This means that the production growth was mainly the result of capital growth. In this case, the changes are explained by the neoclassical theory of convergence. Table 3 presents the results of the estimation of the dynamic CobbDouglas function according to formula (4). The analysis of the results leads to the conclusion that the coefficients of production flexibility against capital $\left(\alpha_{1}\right)$ and labour $\left(\alpha_{2}\right)$ can be considered statistically significant at the significance level of 0.10 . Whereas, the parameter describing the technological progress at the level of 0.112 . The estimated econometric model explains $99.4 \%$ of the total variability of production in the analysed period and is free from the autocorrelation of the random component.

Interpreting the results of the evaluation, we say that in the analysed period $1 \%$ increase in capital measured with the net value of fixed assets contributed to an $0.65 \%$ increase of the GDP, provided the stability of employment was maintained. While a $1 \%$ increase 
Table 1. Pearson correlation coefficients

\begin{tabular}{ccc}
\hline Dependent variable & \multicolumn{2}{c}{ Independent variables } \\
\hline$Y$ & \multicolumn{1}{c}{$\mathrm{L}$} \\
\cline { 2 - 2 } & -0.382 & 0.996 \\
$\ln Y$ & -0.470 & $\ln C$ \\
\cline { 2 - 3 } & & 0.989 \\
\hline
\end{tabular}

Table 2. The results of estimation of the static production function

\begin{tabular}{cccc}
\hline Parameter / Verification measure & Parameter assessment & Value of the T statistic & Critical level of significance \\
a1 & 1.176 & 29.935 & 0.000 \\
a2 & 0.288 & 1.864 & 0.099 \\
R2 & 0.991 & $x$ & $\times$ \\
F-stat [Godfrey test] & 0.461 & $\times$ & 0.519 \\
\hline
\end{tabular}

Note. Own study based on Central Statistical Office data and the MFit software.

Table 3. The results of estimation the dynamic production function

\begin{tabular}{cccc}
\hline Parameter/Verification measure & Parameter assessment & Value of the T statistic & Critical level of significance \\
a1 & 0.653 & 2.252 & 0.059 \\
a2 & 0.268 & 1.962 & 0.091 \\
a3 & 0.032 & 1.820 & 0.112 \\
R2 & 0.994 & $\times$ & 0.663 \\
\hline
\end{tabular}

Note. Own study based on Central Statistical Office data and the MFit software.

in average employment in the economy caused the GDP growth of $0.27 \%$, with stable capital levels. In the period in question, the average annual GDP growth amounted to $3.25 \%$ due to technological progress. This means that the main factor behind the economic growth in 1998-2008 was the technological progress taking place in the economy.

\section{Conclusions}

Both the static and the dynamic function describe well the relations between production on the one hand and capital and labour on the other. In both cases, the la- bour factor was statistically less significant than the capital factor.

Changes in the net value of fixed assets (capital) influenced the GDP growth stronger than changes in employment. This follows from the fact that in the years 1998-2008 there was a low negative correlation between GDP and labour, with a strong and positive correlation between GDP and capital. The obtained results confirm the specificity of the national economy undergoing structural changes requiring in the first place increased investments in fixed assets and replacing labour-consuming technologies with labour-sav- 
ing ones. The dynamic Cobb-Douglas function shows that the GDP growth during a given period determined technological progress. It probably contributed to changes in employment levels (decrease) resulting from the increase in labour productivity.

\section{References}

Aiyar, S., \& Dalgaard, C. J. (2009). Accounting for productivity: Is it OK to assume that the world is Cobb-Douglas? Journal of Macroeconomics, 31(2), 290-303.

Bałtowski, M., \& Miszewski, M. (2007). Transformacja gospodarcza $w$ Polsce. [Economic transformation in Poland].Warszawa: PWE.

Ben-David, D. (1993). Equalizing exchange: Trade liberalization and income convergence. Quarterly Journal of Economics, 3, 653-679.

Berman, E., Bound, J. \& Machin, S. (1998). Implications of Skill-Biased Technological Change: International Evidence. Quarterly Journal of Economics, 113(4), 1245-79.

Bukowski, M., \& Dyrda, S.. (2009). Makroekonomia procesu zmiany technologicznej [Macroeconomics of the process of technological change] (chapter 2). In M. Bukowski and J. Zawistowski (Eds.), Zmiana technologiczna na polskim rynku pracy [Technological change in the Polish labor market]. Retrieved from http://analizy.mpips.gov.pl/ index.php/raporty-i-publikacje-topmenu-58/32opracowania-tematyczne.html

Burda, M., \& Wyplosz, Ch. (2000). Makroekonomia. [Macroeconomics]. Warszawa: PWE.

Caselli, F. \& Tenreyro, S. (2005). Is Poland The Next Spain. NBER Working Papers, 11045, 5-10.

Clark, C. (1940). The Conditions of Economic Progress. $3^{\text {rd }}$ ed. London, UK: Macmillan.

Ćwikliński, H. (2000). Polityka gospodarcza. [Economic policy]. Gdańsk: Wydawnictwo Uniwersytetu Gdańskiego.

Fisher, A. G. B. (1939). Production, Primary, Secondary and Tertiary. The Economic Records, 15(1), 24-38.

Fourastie, J. (1954). Die grosse Hoffnung des zwanzigsten Jahrhunderts. [The great hope of the twentieth century]. Köln-Deutz.

Główny Urząd Statystyczny. (2001) - (2009). Roczniki Statystyczne RP. [Statistical Yearbooks of Poland]. Warszawa: GUS.
Jalava, J., Pohjola, M., Ripatti, A., \& Vilmunen, J. (2006). Biased Technical Change and Capital - Labour Substitution In Finland 1902 - 2003. Journal of Macroeconomics, 6(8), 1-15.

Miller, E. (2008). An assessment of CES and CobbDouglas production functions. Congressional Budget Office Working Paper, 05, 1-20.

Mulat, T. (1980). Capital - Labor Substitution in the Ethiopian Manufacturing Industries. Developing Economies, 18(3), 275-587.

Pońsko, P. (2000). Optymalizacja dynamiczna wzrostu gospodarczego. [Dynamic Optimization ofeconomic Growth ].Warszawa: Elipsa -WSHiFM.

Ripatti, A., \& Vilmunen, J. (2001). Declining Labor Share - Evidence of a Change in the Underlying Production Technology?. Bank of Finland Discussion Papers, 10, 1-14.

Tokarski, T. (2003). Specyfikacja funkcji produkcji a równowaga długookresowego wzrostu gospodarczego. [Specification of production functions and the balance long-term economic growth]. Ekonomista, 3, 341-363.

Tokarski, T. (2010). Przestrzenne zróżnicowaniełącznej produktywności czynników produkcji w Polsce. [Spatial variation of total productivity factors in Poland].Gospodarka Narodowa, 3, 23-39.

Weller, J. (2001). Economic reforms, growth and employment: Labor markets in Latin America and Caribbean. Chile: ECLAC.

Wojtyna, A. (Ed.). (2010). Zależności między produktywnościa, dochodami i zatrudnieniem $w$ krajach na różnym poziomie rozwoju. [Relationships between productivity, income and employment in countries at different stages of development.] Warszawa: PWE.

Zienkowski, L. (2002). Efekty transformacji i perspektywy rozwoju gospodarki polskiej. [Effects of transformation and development prospects of the Polish economy]. In A. Welfe (Ed), Modele $i$ polityka makroekonomiczna [Macroeconomic Models and Policy] (165-189). Warszawa: PWE. 
